\title{
1995年兵庫県南部地震による既製コンクリート杭の 被害様相についての一考察 \\ AN INVESTIGATION ON ASPECTS OF DAMAGE TO PRECAST CONCRETE PILES DUE TO THE 1995 HYOGOKEN-NAMBU EARTHQUAKE
}

\author{
杉村義広*，カルキーマダン**，三 过和 弥*** \\ Yoshihiro SUGIMURA, Madan B. KARKEE and Kazuya MITSUJI
}

\begin{abstract}
Aspects of damage at deeper underground part of precast concrete piles, subjected to lateral flow at liquefied reclaimed land during the 1995 Hyogoken-Nambu earthquak, referred to as the K-shaped failure in this paper, are investigated. Attempt is made to utilize the distributed load method, proposed earlier by the first author, to estimate the cause of this type of failure. Results of the analysis show that the stress in pile at the slip surface exceeds the ultimate strength and, it is effective and important to consider relatively specific loading condition, consisting of the concentrated load at the slip surface in combination with the distributed load due to active earth pressure, to portray the observed behavior.
\end{abstract}

Keywords: Precast conrete piles, Earthquake clamage, Shear failure, Lateral flow, Infinitely long piles, Theoretical solution to horizontal resistance of piles

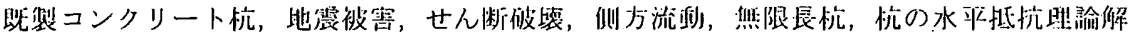

1. はじめに

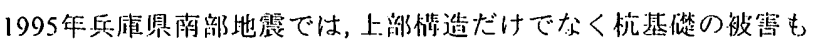
少なからず認めら机，とくに使用例の多い既製コンクリート杭の被

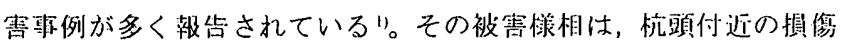

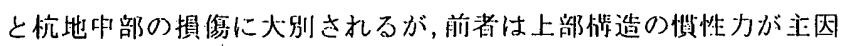

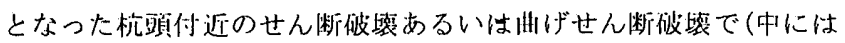

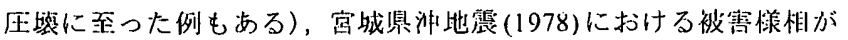
再現されたものであることを篗者らも緑り返し指摘したことがある 2),3)。後者は，埋立て地での被害が典梨的な例であり，坦立て層が洨 状化し，侧方流動寸ることによって引き起こされた沓立て層境界付

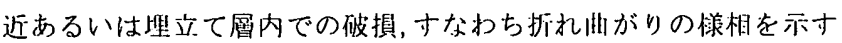

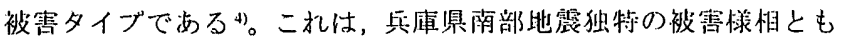
言え，後述寸る上うに，その後この垷臬を解粎寸るための多くの作 究がなされているが, 本論文でもこの既裂コンクリート杭の被霉タイ ブについて新しい洘え方に基づく想定メカニズムを槛筑することによ り考察を与えることを陚みる。

\section{2. 側方流動による杭の典型的な被害形式とその解析に関する研究} 䇠者らが行った文献調查に上机ば, 液状化後の側方流秒による被

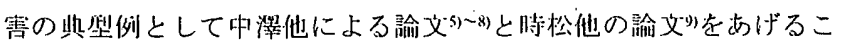
とができる。これらに其通しているのは，建物を支持している海侧
と陸側の杭の被害様相が全く唭なり，とくに淮侧の杭が地中部で 「く」の字犁に折れるような被箐推定イメーシ図として余されている ことである(以下，この些梨的被害䚲式走「く」の宇梨損賃と略記寸 る)。また，他の例では，撤去を余儀なくされた建物の㸡查に際して とか，上部㩐造はさしたる㩐造的被害がないのに傾斜し，その復旧の

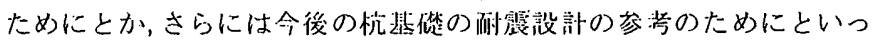

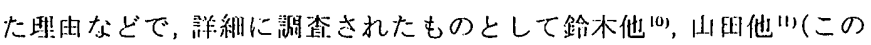
事例汢SC+PHC+STの継忼の中杭であるPHC杭部分が提賃したのが特 徽的)，松村他吕があげられるが，い寸゙れも前述の被管推定イメージ

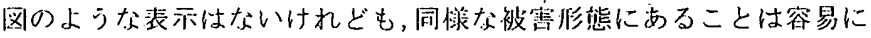
推察できる。さらに詳細さはやや火けるが，一般的な紴害タイブを示

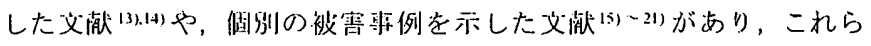

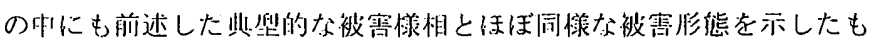
のが含末れていると推定できる。

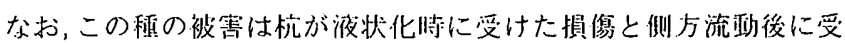

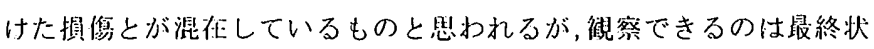

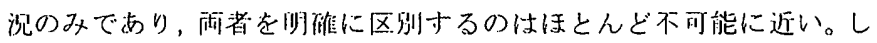
たがって、ここでは「淮状化による被害」とのみ表現されている諭文 は省くことにし，液状化吟にも何らかの掑情を受けた可能性はある

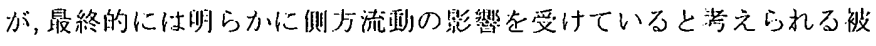

* 東北大学大学院都市・建築学尃攻 教授・工博

** 秋田県立大学建築環境システム学科 教授・工博

*** 東北大学大学院都市・建築学専攻 助手. 工修
Prof., Dept. of Architecture and Building Science, Tohoku Univ., Dr. Eng. Prof., Dept. of Architecture and Environment Systems, Akita Pref. Univ., Dr. Eng. Res. Assoc., Dept. of Architecture and Building Science, Tohoku Univ., M. Eng. 
管事例に限ってあげている。遊に，筆者らの判断ではあげておくの が道当と思われても，侧方流動の影響は受けていないと明記されて いるためにあえてはずした文献22)や，僋方流動を経駼しているが杭 種が場所打ちコンクリート杭や銅管杭であるために本論文の目的に はそぐわないためにはずした文献23もあることを断っておきたい。 以上に示した被害事例に刘して，そのメカニズムを解明寸るための 解析的研究も精力的に行われている。その包括的なまとめと位监一うけ られるものとして，ここでは地盤工学会が 1998 年 5 月に行ったシン ポジウムの委貝会融告をあげたい24)。それによれば，侧方流動後の状

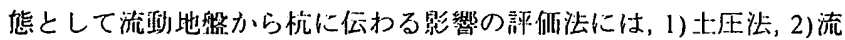
作压法，3）応答変位法があり，各機関による椎造物の設計法としてこ れらのうちいずれかが埰用されているとしている。地震応答解析によ る倹計は当然ながら解秋泣の一つであるので,それを加えれば既往の 解析的破究は寸べてこれら4つのうちのどれか，あるいは複命们に用 いている例が多い。例えば，上压法と流体泟法は㩒質をどう考えるか の堂いで，市る意味では通じるものがあるため小朴他25恃网者のメ力

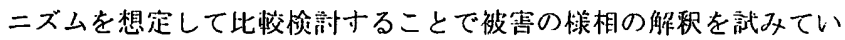
る。侁腹他 ${ }^{26)}$ は土圧法を用いているが（論文中では場所打ちコンク リート杭を念頭において杭諸元を設定したとあるが触析沾一般である のであげておく)，比㕮のために後述の㐫答変位法の邀用も就みてい る。また，流体压法を用いた例としては難波他27.281，藤木他州があげ られる。応答変位法を用いた例は最も多く，山穴他 ${ }^{301}$ ，石坂他 ${ }^{31)}$ ，伊

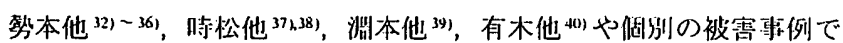
も示した永野他"1)をあげることができる(ただし，事例が非常に多い ので作究グループごとに類似のものは省くとともに代表的と思执れる 文献のみに絞っている)。

以上の 3 つの評㖇法には共通している点がある。それい流慟地船 が杭を「押寸」寸なわち背後から外力として作用寸るという考えおで

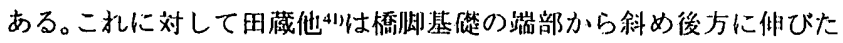

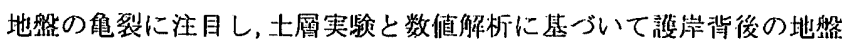
が前方移動寸ることで，才かわ橋卯前方に存在していた地盤が头わ れることで生じたもので, 流動地盤が背後から抑寸力となって作朋し たのではないと主脤している。この舴釈は根切り工事における「除荷

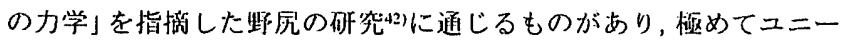
クな澕え方として注目に值しよう。

地震灾答解浙に基ついて侧方流動による被害のメカニズムの解秋 を試みた砳究も多く，応答変位法の場合と同様に碳究グルーブごと に颣似のものは省くとともに代表的と思われる文献のみに絞って拾い

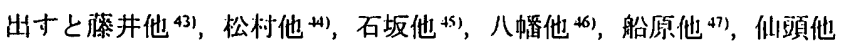

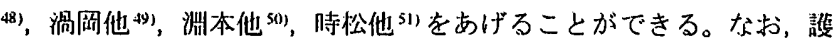
岸近傍に建つ仮想の建物を対象とし，場所打らコンクリート杭支持を

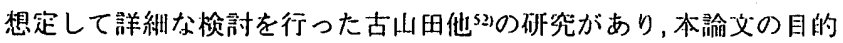
には直接にはそぐわないものの閑復的には参考となる点が多く指摘さ れているので, 㐌えてあげておく。才なわち，護岸からの距濉に応じ て㚇答変形モードが異なり，近いと大きく遠いと小さくなること，地 盤流動が始まる以前に忼の跬性化が始まっていると推定されること， 海僛の杭は杭頭部での変位が陸侧の杭の存在によって抑えられる佂向 にあり，地中部では侧方流䅱で地盤が海侧にせりだす哚さで塑性化す ること，逆に陸側の杭では杭頭部で海側の杭に引かれて塑性化が進む とともに地中部では波状化により然性化が進むことなどである。
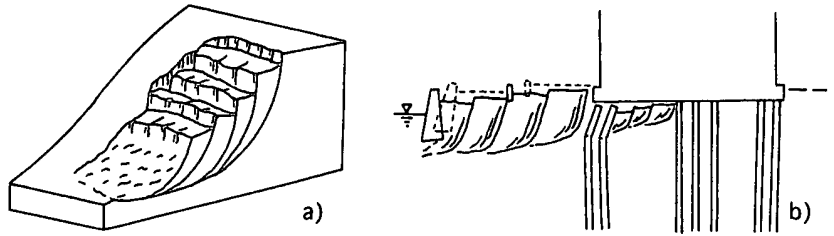

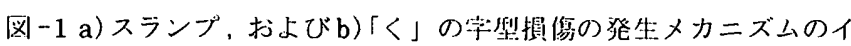
メージ図

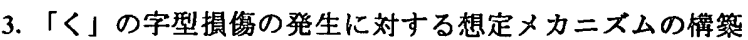

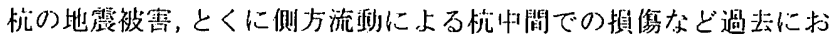

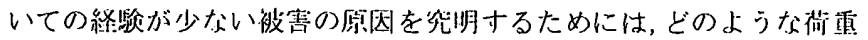
作朋があったかを合わせて学えることが重椠である。以下には，代裴

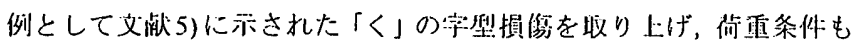
あわせてその発坐の愳定メカニズムの椺筑を陚みる。

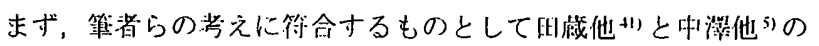

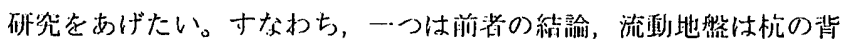
後から挷寸形で作用したのではなく，前於から陮れていくとの見解 でありほかの一つは後者に被害イメージとして示されている沿り 洎の考え方である。これらの符合は，侧方流的が地滑りの分野で言 うスランブ（図-1a）に似た結果となって見れたのではないかと篗 者らが考えていたことによる。次に，硋当脡物とその䦌辽状沉に注

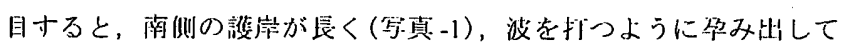

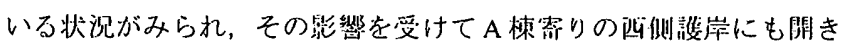

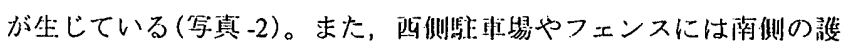
岸の移動に誘発されたと思われる幾重かのひび别れが生じており(写

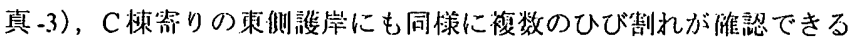

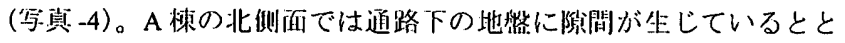
もに，5m程度平前(北)侧に建物面と平行寸る地制れが走り，その影 響でコンクリートスラブが制れて段虚が山来ている(写真 -5)。写 真-3や字真-4 などでは大きな地制れ恃建物艮非方向と平行に $5-7 \mathrm{~m}$ （ほほ建物短辺の半分に対応寸る）幅で生じているともみられる。こ れらの状況と先の二つの文献から得たヒントを組み合わせて，被害

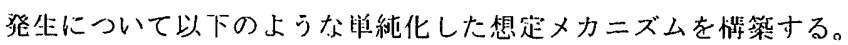

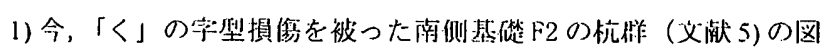
2）を対象として図－1b)に示寸ようなメカニズムを想定寸る。まず，

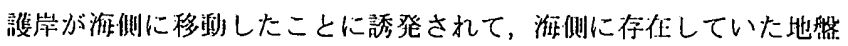

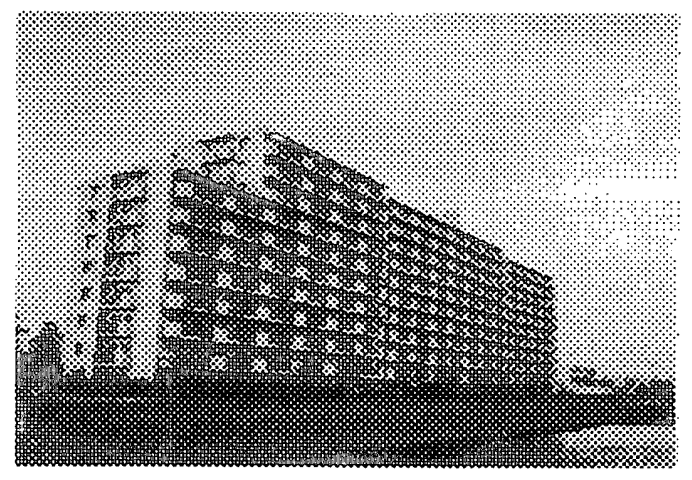

写真-1 南東侧からみた棑物の全景

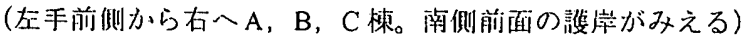




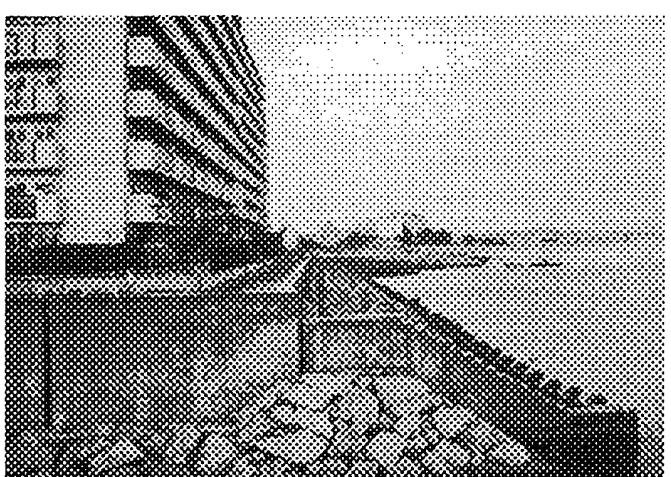

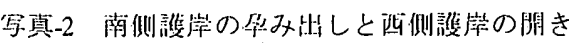

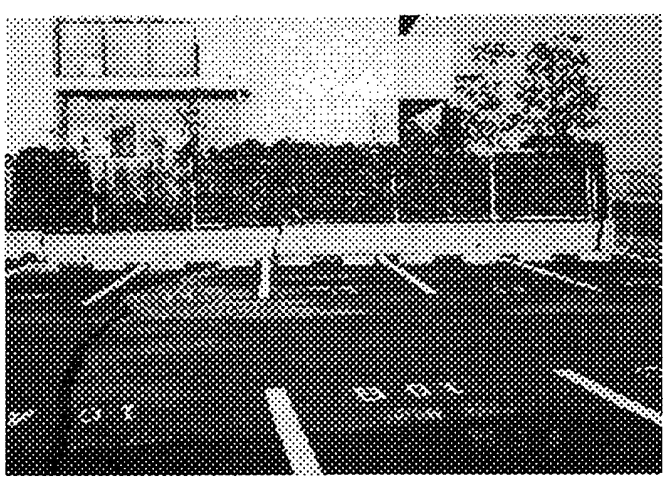

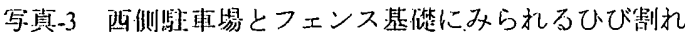

がブロック状に滑りを生じて忼脽から雕れたと推定する。このこ とによって杭闲側の水平応力のバランスが崩れるが，この状沉は

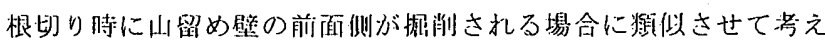

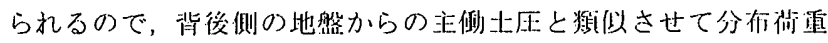
を仮定寸る。ただし，水压との区㓢が付きにくい流酎地盤となっ ていることを想定して一休的な側王で孚えることにし，侧圧倸数

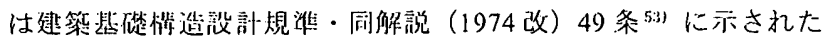

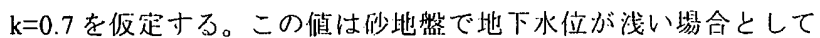
提案されているものであるが，比粉的通常の地盤の場合に想定さ れる $\mathrm{k}=0.5$ と，今国の上うな液状化地盤など特殊な場合にはむし 万 $\mathrm{k}=1.0$ と想定される偲の中關值であり，被害原因のための想定 值としては控えめの值と考えられる。

2)次に, 水平応力のバランスが崩れたことに誘発されて，引き続 いて中央部の杭样位犆までの地盤内に滑りが生じ，その滑り力が斯 礁F2の杭破に作用したと推定寸る。その位䠄は，多くの文献に上

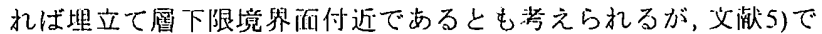
は埋立て屬内で滑りが起きたとの推定が明記されているので,ここ ではそれにならって GL-4.1m程度の深さで生じたものと寸る。滑り

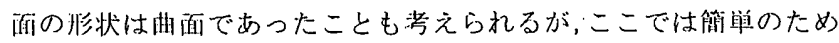
に汹面と仮定し，滑り面での杯憏抵抗力以上の力が作朋したときに 滑りが生じるとの条件で滑り力を求めることにし，集中荷覱として 作用させる(ただし、この位监でも滑りはブロック状に起こった可 能性を劣虑して，解忟では滑り唇さを $2 \mathrm{~m}, 4 \mathrm{~m}$, 建物の半愊に相当

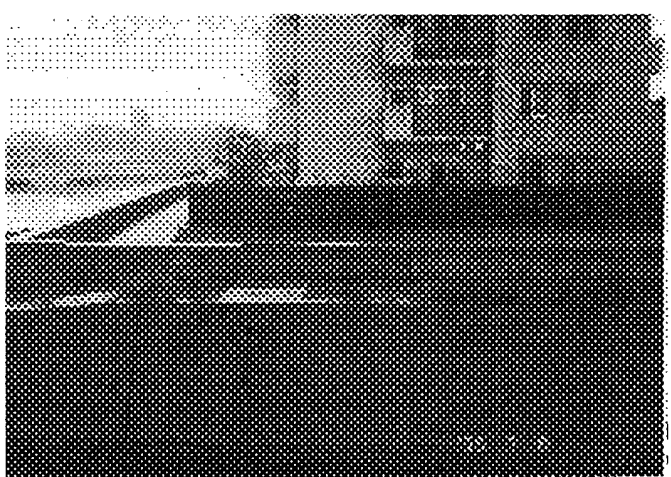

写真4 東側熦岸にみられるひび制れ

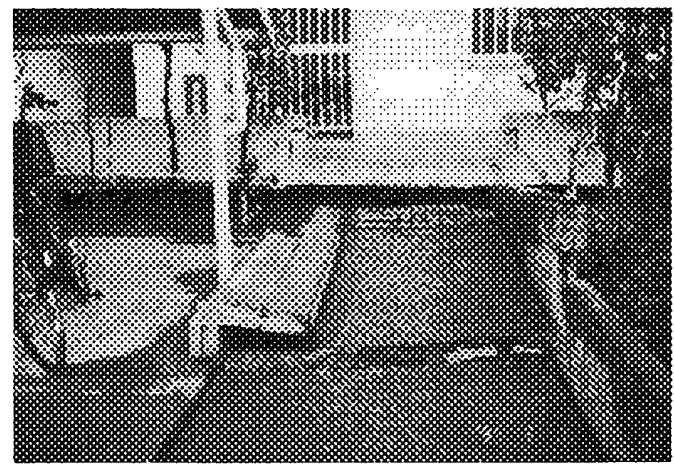

写真-5 A 梀北侧の状況

(通路下に陾間が生じているとともに $5 \mathrm{~m}$ 程度手前側に建物と平行寸る 地制れぶ見える)

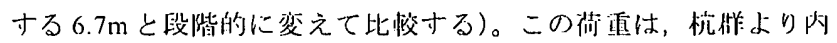

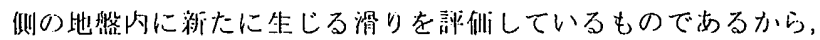

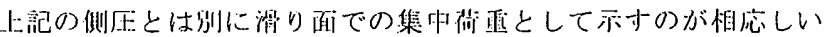
外力で汤ると潦えられる。

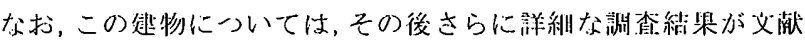
8)で示されており，文缺5)では保机られていなかった事実，才なお ち䎲通りの杭7本にはやや深い GL-4.7m付近で佊断していることが

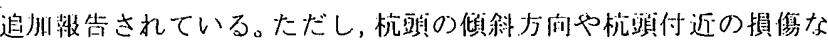

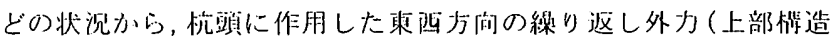
の慣性力と帣えられる)がその主因であると推定されている。この

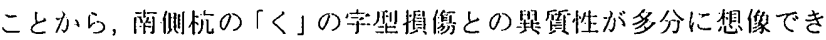

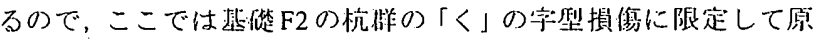

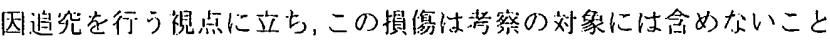
にする。

以上のように，対秝とした杭作より海侧地盤内での滑りが発生 し，それに上る水平态力のバランスの崩れが生じるとともに，杭棚

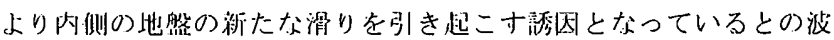
状的な滑りを想䇥している点が本論の想定メカニズムの恨苟であ

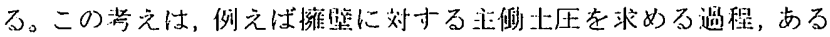

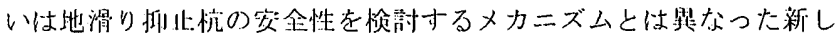

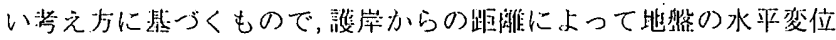
の大きさに婆化が生じたと言われていることにも通じることになる

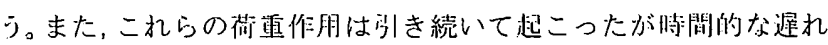


はそれほど大きくはなく，水平応力のバランスが筋れている状黛で 背後からの滑り力を受けたと推定しているので，後述寸る籍便な静 的解析沙ではこれらを同時に作用させることに寸る。

なお，この解析法では基本的に杭の全長にわたって地船反力が作用 寸るものと扱っており，上記 1)に示した南側地盤が杭から陮閏して いるとの仮定とは矛盾寸ることになる。したがって，解析においては 地盤反力がかい堭合のアナロジーとして滑り面以浅の地盤反力倸数を 非常に小さくした場命の計算も追加して考察することにする。

\section{4. 荷重分布法の適用}

筆者らは以前から应答变位法に対して荷重分布法なる解析法を提案

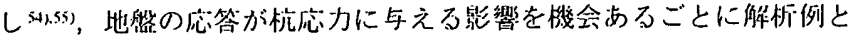

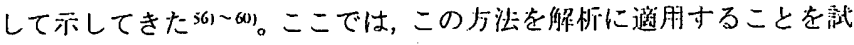
みる。

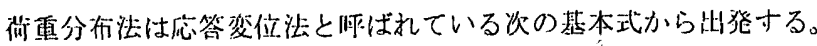

$E I \frac{d^{4} y}{d x^{4}}+k_{h} B\{y-f(x)\}=0$

ここで，EIは杭の曲げ剛性， $k_{h}$ 以水汇地䲍反力保数， $B$ は杭幅， $y$ は 杭の水平変位, $f(x)$ は地䑪の水平变位, $x$ は澘さである(单位は $\mathrm{KN}, \mathrm{cm}$ 系を用いるのが监通)。 $f(x)=0$ と監けば通常の杭頭に集中水平力を受 ける杭の水平抵抗䦔題の基本式と一致することが分かる。今（1)式を 変形すると次式になる。

$E I \frac{d^{4} y}{d x^{4}}+k_{h} B y=k_{h} B f(x)$

寸なわち，右辺の $k_{h} B f(x)$ は見かい上外力とみることができるので，任 意外力分布 $p(x)$ で筧き換えてみると次式が得られる。

$E I \frac{d^{4} y}{d x^{4}}+k_{h} B y=p(x)$

(2) 式は外ナ分布が $k_{h} B f(x)$ で嫢定されているのに対し，(3)式は $p(x)$ 羊任意に与.えられる形になっていることが特微的である。すなわち，

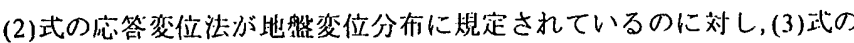
何重分布法は任意形状の仯重分布を与えられる点が翼なっている。さ らに言えば，苝重分乍法は林論文で対象としている滑りなど，地船破 媜の閔題への応用も可能と学えられる。そこで，前章で示した集中荷 重や分布荷重への対応を試みることができる。

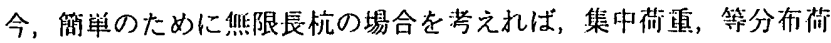
重，三角形分布荷重などの任意荷重に対寸る杭の変位や空力の一般解 は寸でにHetenyi (1)によって求められているが，同様の解を求める乎順 は文献 55)に比洨的詳䊼に示したのであわせて参照されたい。ここで は，得られた結果のみを裴-1に示寸。同表では三的形と逆三的形分布 荷重の場合とも解を示したが，雨者を加算寸ると等分布荷重の解に一 致していることが確か女られよう。これらの分布荷重の組合わせを適 用した解析例を次章に示寸。なお，本論文に先立って同様の応用を試 みたことがあるので (2),63)，あわせて亦しておく。

\section{5. 数値解析例}

梅造諸元などは最終的なまとめである文献8)の記述を参考に寸る と，基礎スラブは $0.4 \mathrm{~m} \times 1.8 \mathrm{~m}$ (そのうち地中への根入扎は $1.5 \mathrm{~m}$ )，杭

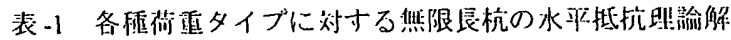

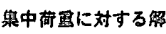

\begin{tabular}{|c|c|c|c|c|c|c|}
\hline \multirow{5}{*}{$x_{a}$} & $y$ & & $x_{t} \leq x_{0}$ & $x_{0} \leq x_{0}$ & \multicolumn{2}{|l|}{ Explanations } \\
\hline & \multirow{4}{*}{$\hat{x}_{c}$} & & \multirow{2}{*}{$B_{a}$} & \multirow{2}{*}{$\begin{array}{c}B_{b a} \\
Q_{h a}\end{array}$} & \multirow{4}{*}{\multicolumn{2}{|c|}{ 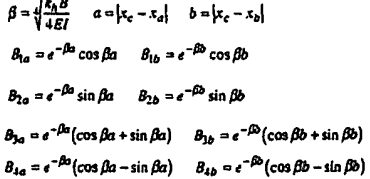 }} \\
\hline & & & & & & \\
\hline & & $M_{c}=\frac{P}{4 B}$ & $B_{4 a}$ & $B_{40}$ & & \\
\hline & & $Q_{c}=\frac{P}{2}$ & $\boldsymbol{g}_{a}$ & $-B_{1 a}$ & & \\
\hline 整分南 & に対 & 万䐆 & & & & \\
\hline & $y$ & & & $x_{s} \leq x_{a}$ & $x_{a} \leq x_{c} \leq x_{b}$ & $x_{b} \leq x_{c}$ \\
\hline & $x_{c}$ & $y_{c}=\frac{\rho}{8 E I \beta^{T}}$ & & $B_{10}-B_{10}$ & $2-B_{14}-B_{10}$ & $B_{16}-B_{10}$ \\
\hline$s_{0} \rho$ & & $\theta_{c}=\frac{\rho}{8 E I \beta^{S}}$ & & $B_{30}-B_{36}$ & $B_{36}-B_{30}$ & $B_{30}-B_{30}$ \\
\hline$x_{p}$ 目 & 16 & $M_{c}=\frac{Q}{4 \rho^{2}}$ & & $B_{2 b}-B_{2 a}$ & $B_{3 A}+B_{30}$ & $B_{20}-B_{20}$ \\
\hline & $x$ & $Q_{c}=\frac{P}{4 \beta}$ & & $B_{t a}-B_{2 b}$ & $B_{d a}-B_{d b}$ & $B_{4 a}-B_{4 b}$ \\
\hline
\end{tabular}

这三角形分布荷重に対する你

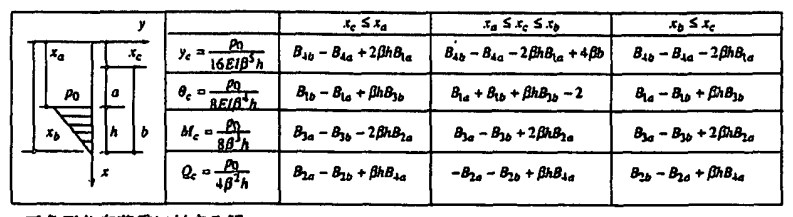

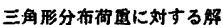

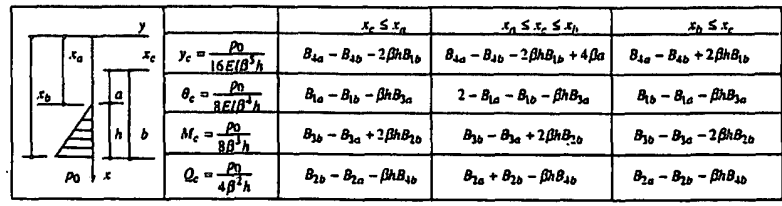

は PC 梳 A 侕 $(\phi=50 \mathrm{~cm}, t=9 \mathrm{~cm}, L=13+13=26 \mathrm{~m}$, 艮期詐容支持力 ${ }_{L} R_{a}=764 \mathrm{kN} /$ 标) であり，㑲侧の杭が $\mathrm{GL}-3.8 \sim 4.2 \mathrm{~m}$ で水平に破断し

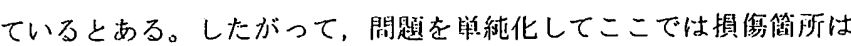

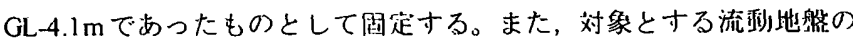

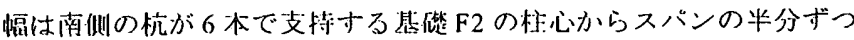
をとった $6.3 \mathrm{~m}$ を単位に考えることにする。

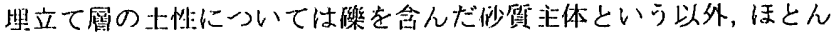

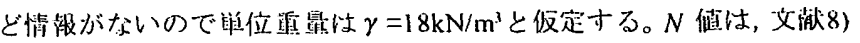
の図からは大きな値が沾み叹れるが，通常，埋立て上では中に含まれ

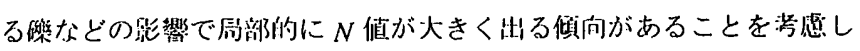
て、ここでは埋立て層全休に対してやや小さぬに $N \doteqdot 15$ と推定寸る。

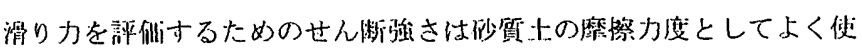

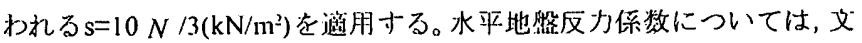
献 64)に示された次式走速用寸る。

$k_{h 0}=\alpha \xi E_{0} B^{-3 / 4}$

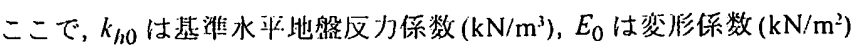

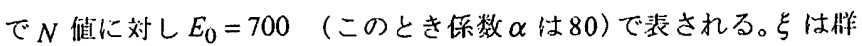
杭による影骂係数で杭中心間隔/杭径比 $(\kappa)$ が 6 以下の場合に $\xi=0.15 \kappa+0.10$ で裴される。今回の解析例では， $\kappa$ は文献8)の图から

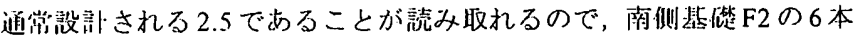
の場合, $\xi=0.475$ となる。B は哭次元化倸数で杭征を $\mathrm{cm}$ で裴した場

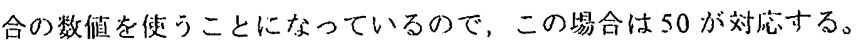
これらの数陋を(4) 式に代人寸ると最終的に $k_{h 0}=2.122 \times 10^{4}\left(\mathrm{kN} / \mathrm{m}^{3}\right)$ が得られるので、この值を用いることにする。

以上の条件で滑り面以浅での侧压と滑り面に拉ける滑り力を求ぬ 杭 1 本当たりに换算寸ると，図-2に示したような台形分布修重と集 


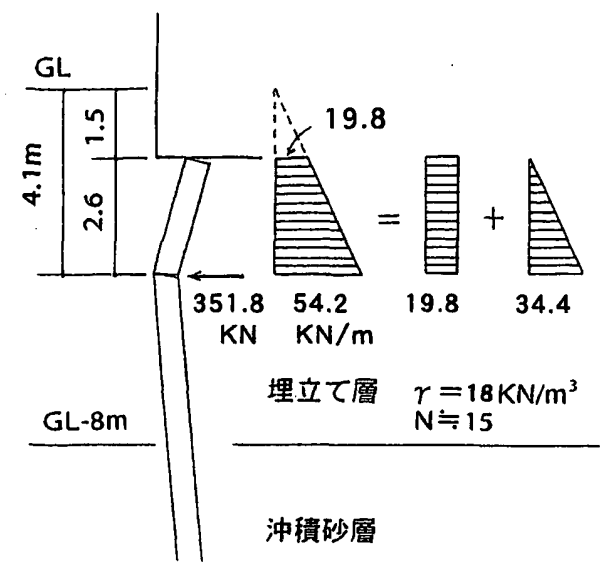

図-2 典梨的な被害形式と想定才る莎重分柿

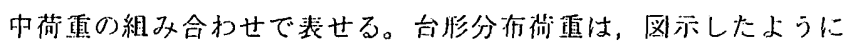
$19.8 \mathrm{kN} / \mathrm{m}$ の等分行荷重と GL-1.5mで $0 \mathrm{kN} / \mathrm{m}, \mathrm{GL}-4.1 \mathrm{~m}$ で $34.4 \mathrm{kN} / \mathrm{m}$ と

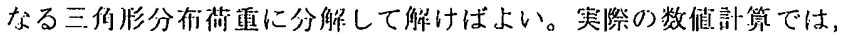
杭頭位盟(GL-1.5m)加 GL-10m までを $0.1 \mathrm{~m}$ 間临で86点についての) 応答檤を求めることにする。

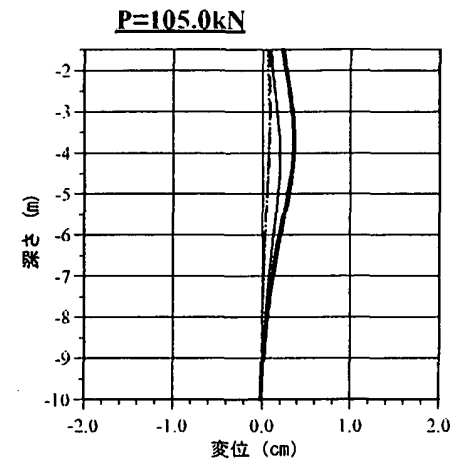

$P=210.0 \mathrm{kN}$

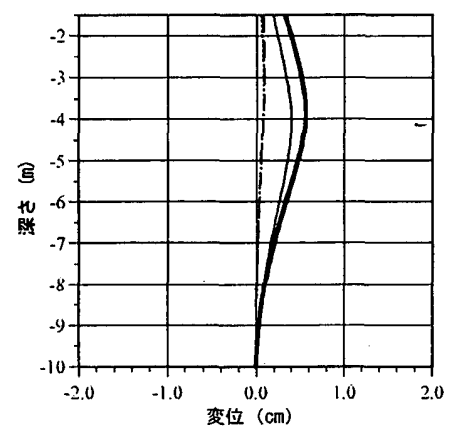

$\mathrm{P}=351.8 \mathrm{kN}$

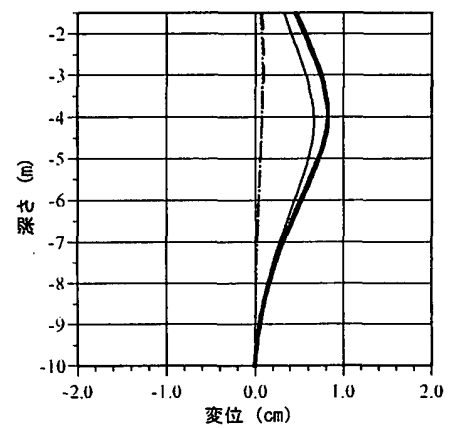

\section{6. 数值解析結果に対する考察}

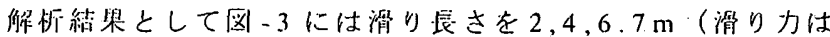
$105,210,351.8 \mathrm{KN}$ に相当）に変えた時の杭の変位，州げモーメント，せ 儿断力の変化状沉を示寸。末た图-4には，前述した地盤反力がない場 合のアナロジーとして図-3に拉ける滑り力351.8KNの場命に対し，滑 り面以浅の地盤反力倸数を 0.1 倍と 0.01 倍した場合の諳算例を示寸。

以上の曲げモーメント図には杭休の終刷曲げモーメント $M_{u}(\mathrm{kNm})$

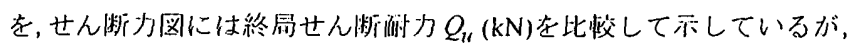

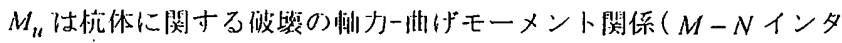

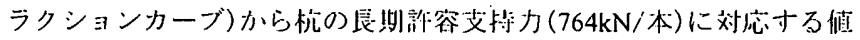
を求めたものである。来た， $Q_{n}$ は文擜65)に示された(5)式と，岸时 ら(の)による(6)式(ただし，林論文のケースに輆当才るものだけに睹 純化して表示) 老比恔榆尌寸ることで求めている。

$$
Q_{u}=\frac{2 t l}{S_{0}} \frac{1}{2} \sqrt{\left(\sigma_{g}+2 \phi \sigma_{t}\right)^{2}-\sigma_{g}^{2}}
$$

$$
\sigma_{g}=\sigma_{e}+\frac{N}{A_{e}}
$$
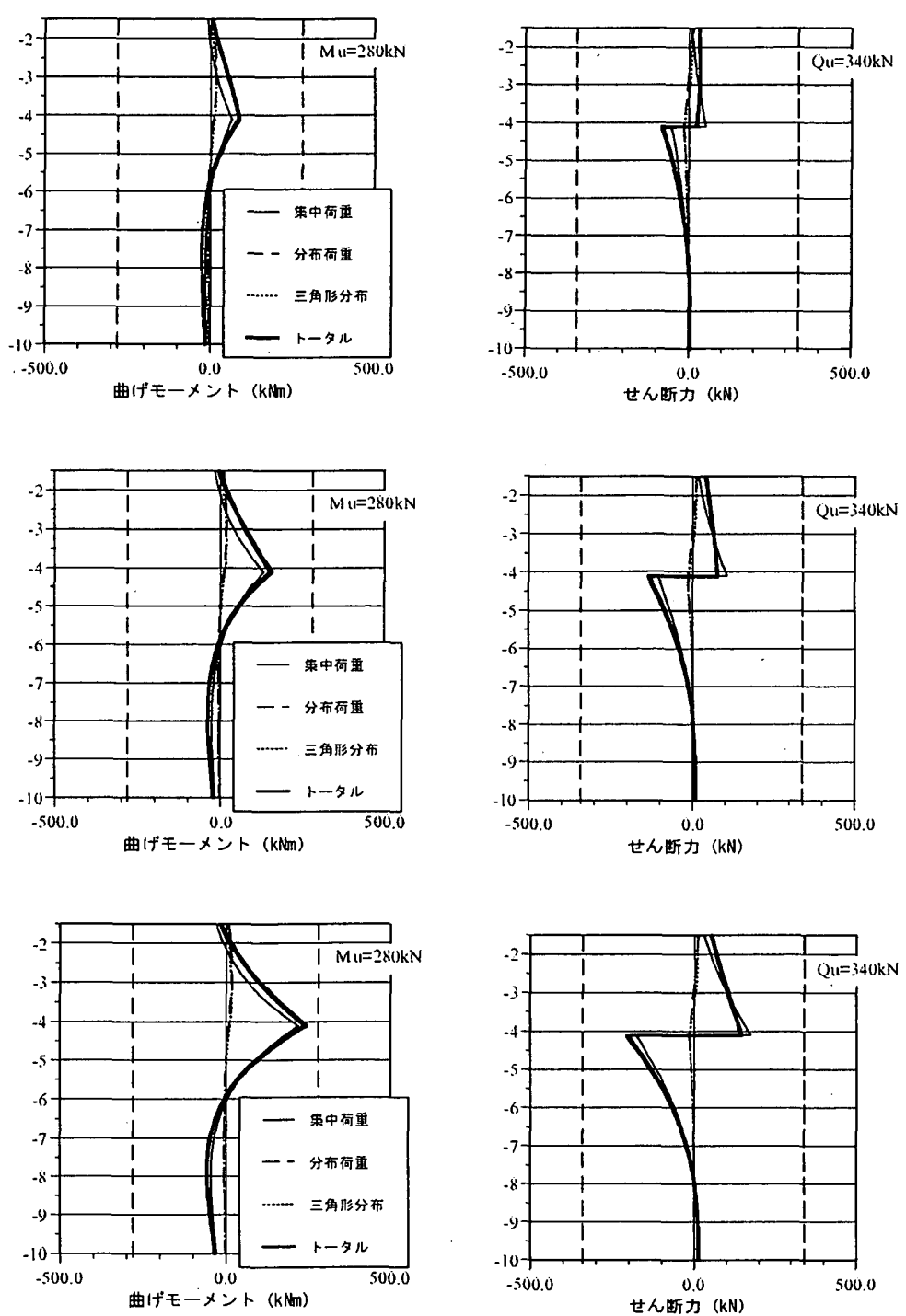

図-3 滑り長さの差買に上る杭の忍答最の变化 
ここで，t，I， $S_{0}$ は杭の肉厚，断陑 2 次モーメント，断而1次モーメ ントであり， $\sigma_{\mathfrak{e}}, \sigma_{t}$ は有效プレストレス，コンクリートの引脹り強

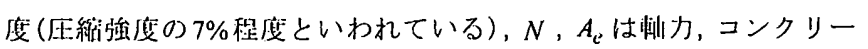
卜の換算断徨積である。番位は計算途中は $\mathrm{kN}, \mathrm{cm}$ 系を朋いるなど任 意であるが，最終的にkNにまとめるのが晋通である。中は，文献65)

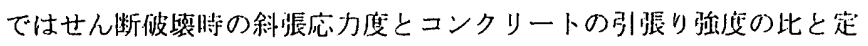
義されているが，事实上は(5)式が烸性諭に基づいた式であるので， 実駼結果と比校したときの諷獘倸数で，0.5程度と寸ると対応がよい と言われている。

$Q_{u}=\tau_{\max } b_{e} j$

$b_{c}=\{-1.24(t / D)+1.19\} A_{c} / D$

$j=7 d / 8=7(D-t / 2) / 8$

$\tau_{\max }=\tau_{1}+\tau_{2}+\tau_{3} \quad$ (梳本体の設部将)

$\tau_{1}=\frac{0.115 k_{u} k_{p}\left(\sigma_{B}+17.7\right)}{(M / Q d)+0.115}$

$\tau_{2}=0.657\left(0.785 p_{w} \cdot{ }_{w} \sigma_{y}\right) \quad\left(0.785 p_{w} \cdot{ }_{w} \sigma_{y} \leq 7.4\right) \quad\left(\mathrm{N} / \mathrm{mm}^{2}\right)$

$\tau_{3}=0.102\left(\sigma_{e}+\sigma_{0}^{\prime}\right)=0.102\left(\sigma_{e}+\frac{N^{\prime}}{b_{e} j}\right) \quad\left(\sigma_{e}+\sigma_{0}^{\prime} \leq 27.4 \mathrm{~N} / \mathrm{mm}^{2}\right)$

ここで, $t, D, A_{c}\left[A_{c}=\pi t(D-t)\right]$ は, 杭 0 闪厚 $(\mathrm{mm})$, 外径 $(\mathrm{mm})$, 笑 断面積 $\left(\mathrm{mm}^{2}\right), \tau_{1} ， \tau_{2} ， \tau_{3}$ はコンクリート負揩分, らせん筋負担分, 杣 力負担分の世ん断応力 $\left(\mathrm{N} / \mathrm{mm}^{2}\right)$ である。 $\sigma_{B}, \sigma_{\mathrm{e}}, N^{\prime}$ はコンクリートの

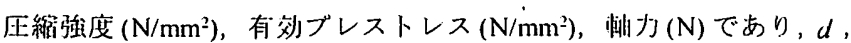
${ }_{w} \sigma_{y}$ 㤌有效せい $(\mathrm{mm})$ ，らせん筋の降伏点強度 $\left(\mathrm{N} / \mathrm{mm}^{2}\right)$ である。

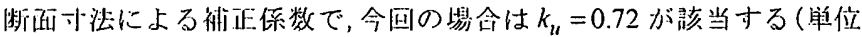

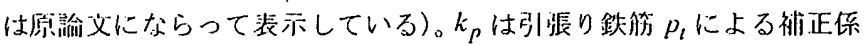
数で次式で裴せる。

$k_{p}=0.82\left(100 p_{t}\right)^{0.23}, \quad p_{t}=p_{g} / 4$

$p_{g}$ は正篎比 $\left(p_{g}=A_{s} / b_{e} j\right), p_{w}$ はらせん管比 $\left(R_{w}=\left(q_{w} / l_{c}\right)\right.$ であり，

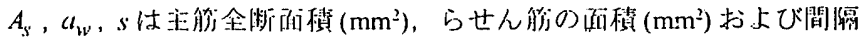

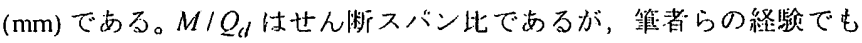

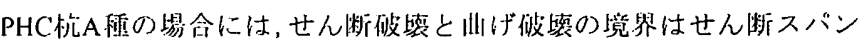
比が1.0程度であることが知られているので67，ここでは1.0を仮定し て筧壮寸ることにした。

以上の部算条件で，帆力として松の）艮期詐容支持力 $(764 \mathrm{kN} /$ 林)を若

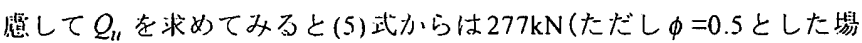
合)，(6)式から恃340kNが得られ，(5)式をせん断ひび绪れ洏力，(6)式

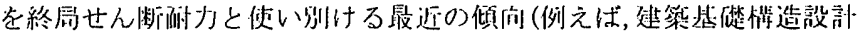

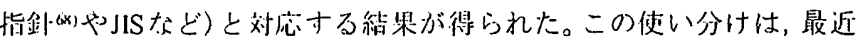
の知見としてせん断ひび制れが生じるまで杭休は線肜的な举歏をし， その後の最大洏力米での伸びもこれらの部算結果に対応寸る程度であ ることが知られるようになってきていることを考えれば妥当なものと 思阮机るので,ここでは(6)式の結果を終局せん断偄力 $Q_{u}$ として採用 オることにする。

図-3では，侧压を图定しているので滑り艮さの增大とともに最大做

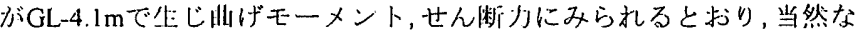

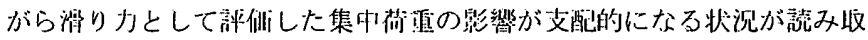
れる。その值は滑り長さ6.7mの場合，それぞれの終局优力に対しては 州げモーメントで8制䖽度，せん断力では 6郜程度の計算絬舆となっ ている。

一方，図-4では様相がー変寸る。地篮反力係数を0.1倍とした場合に

\section{$\mathrm{P}=351.8 \mathrm{kN} \quad(\mathrm{kh}=\mathrm{x} 0.1)$}

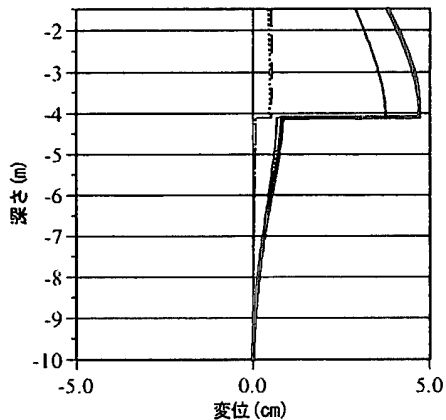

$\mathrm{P}=351.8 \mathrm{kN}(\mathrm{kh}=\mathrm{x} 0.01)$

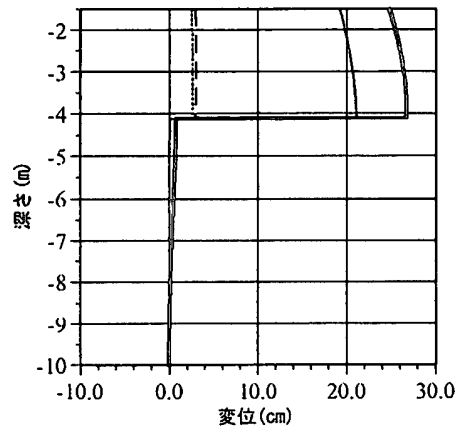

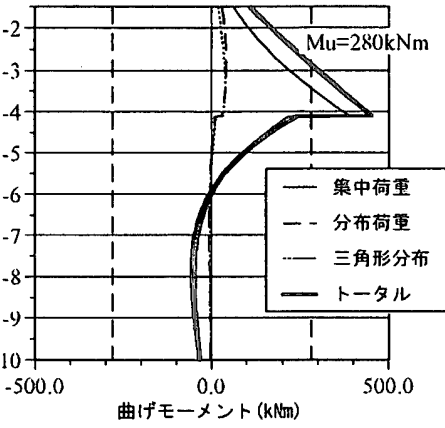

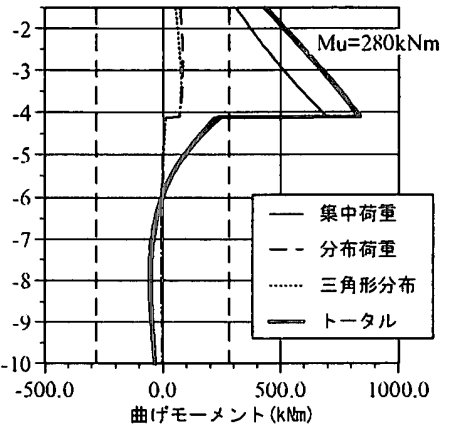

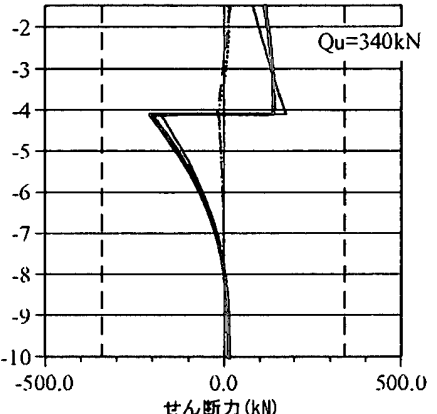

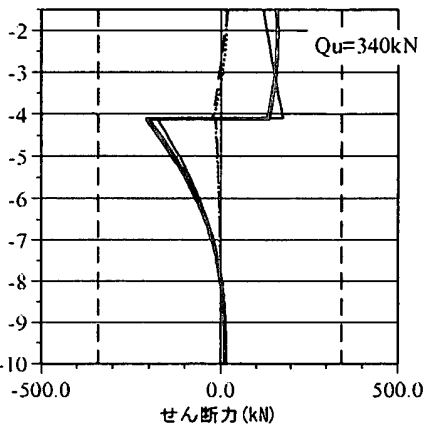

図-4 滑り面以浅の地盤反力倸数の低減に上る杭の心答量の变化 
は，图-3の滑り脣さ $6.7 \mathrm{~m}$ の場合と比校して，世九断力については最大 値がやや大きくなり，滑り陑以浅の分布形状がやや異なるものの総じて 変化は少ないのに対し，曲げモーメント忏分布沜状自休が滑り面付近で

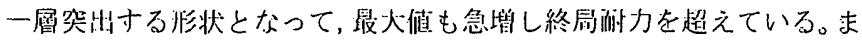
た，変位も滑り陑付近で極端に折れ曲がる形状を示し，全く異なった装 栏となっていることが特微的である。地盤反力係数を 0.01 倍とした埸 合には，さらにその傾问が一層強諯される関倸になっている。この計算

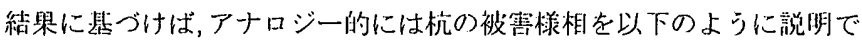
きるように舁われる。「滑り面付近での州げモーメントが儑に終局酎力 を超えてダメージを受けている上にせん断 (それも淔摸せん断梨)の溜

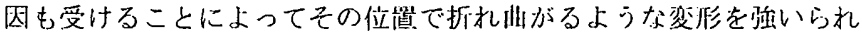
た。ただし，荷電の設定には多くの仮定が含まれているためより精庭

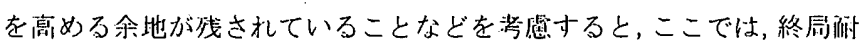

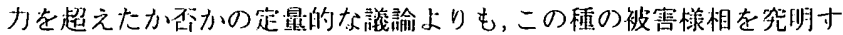
るには, 少なくとも以上に示した分布少重や集中街重の上うな比较的

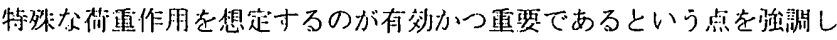

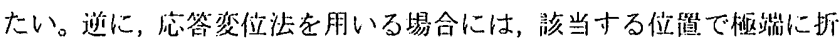
れ曲がるような変形を邂用寸ることが必望になるであろうとも言い掺 えられる。

\section{7. 結論と今後の課題}

以上には，兵㡹県南部地震の際にみられた赞製コンクリート杭の

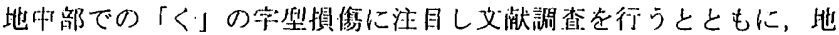
盤の侧方流剩による変状を地滑りの分野でのスランブに似た綃墺と なって現れたとの推諭に基づいて新しい沙え方による想定メカニズ ムを攸筑し，籍者らが提案してきた街重分布法を旗用寸ることで被 害様相の解惞的触郘を試みた。才なわち，侧方流動によって杭の闲 側に作用していた水平応力の一方が垁われることの影響を，胃かけ 上根切りと類似と考えて背後地盤からの僛圧と仮定した台䚲分在荷

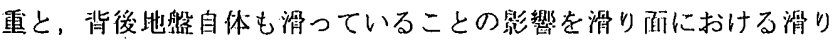
力として仮定した集中荷重が惩限脣仮定の杭に作用寸るものとして 触析を行った。また，滑り面以浅においては地盤反力がないことの アナロジーとして地盤反力倸数を非常に小さくした場合の計算も追 加して学察した。その結喿, 滑り力を作用させた位犆付近でとくに 曲げモーメントが終局耐力を超え，さらにせん断力の效果も㧈扔 て折机曲がるような変形を強いられることが喼められ，この種の被 害槏相の原因を追究才るためにはこれら比校的特䏭な荷重の組み合 わせ作用を想定寸ることが有效でかつ重琶であるとの結諭を得た。

なお，より実状に近い解秋を得るためには，杭頍の境界条件や粦为 の影響，流怔していることによる地盤の強度低下さらには杭休自身の

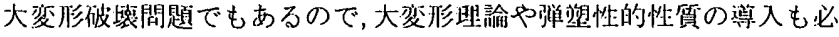
裂となることは言うまでもない。これらの点については今後の辣題と したい。

\section{謝辞}

本論文で用いた写真は，たまたま共同で被害詶查を行うことに なった (怢) ジオトッブのスタッフに提供いただいたものである。こ れらの方々に班査にあたってのご協力に感謝寸るとともに，とくに 写真撮影に携わり提供いただいた上維屋好行氏と山下臂明氏(当洔) には格别の謝意を表したい。また，文献 5)の著者である中澤明夫， 難波伸介の阙氏には私信での問い合扔せにも応じていただいた。こ
こに心よりの謝意を裴したい。

\section{参考文萳}

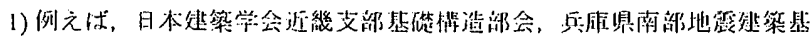

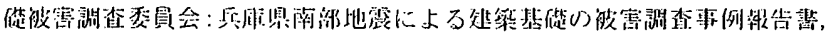
400p., 1996.7

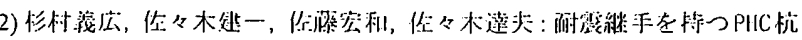

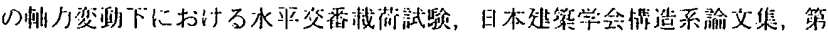
513 号, pp.105-111, 1998.11

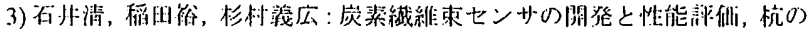

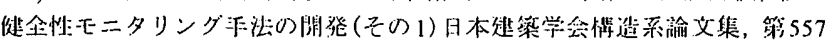
号, pp.129-136, 2002.7

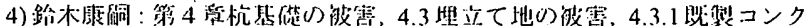

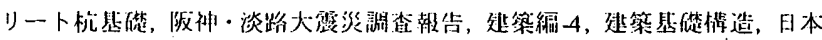

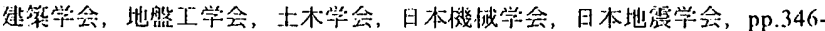
$356,1998.1$

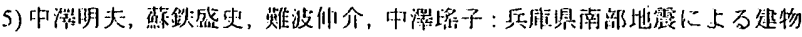

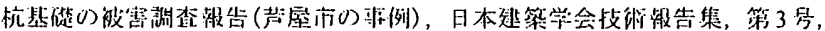
pp. $77-82,1996.12$

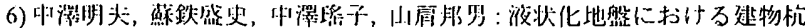

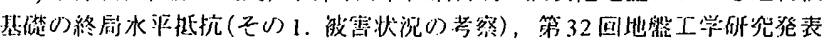
会, pp.1517-1518, 1997.7

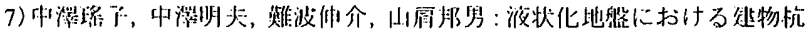

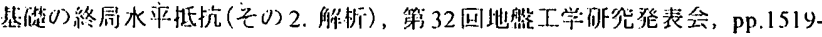
$1520,1997.7$

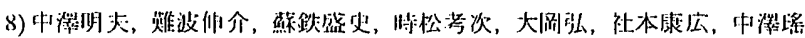

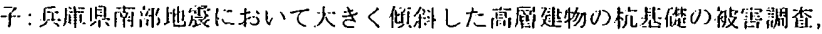

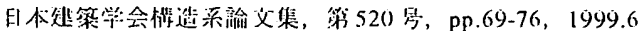

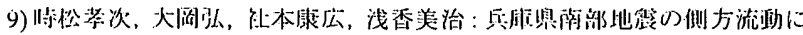

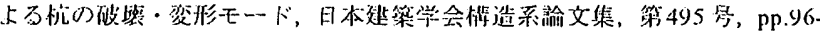
$100,1997.5$

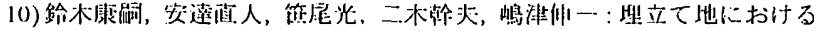

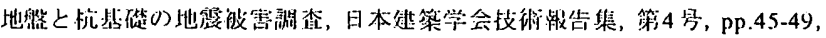
1997.3

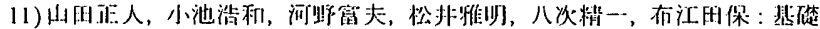

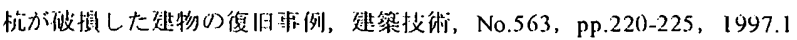

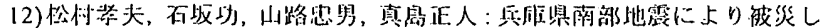

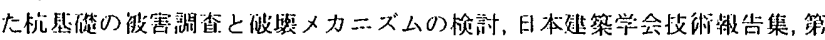
8 晨, pp.79-84, 1999.6

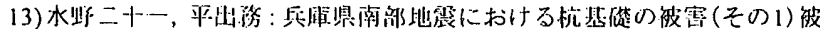

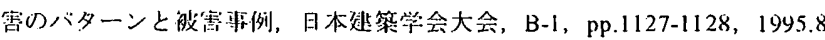

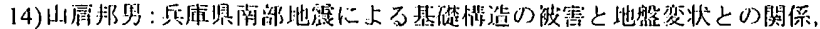

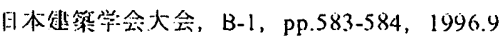

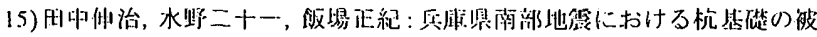

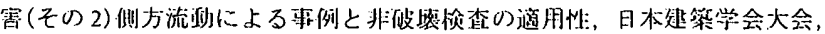
B-1, pp. $1129-1130,1995.8$

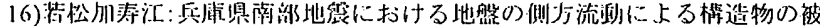

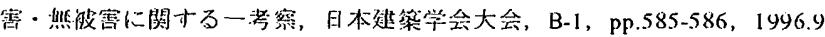

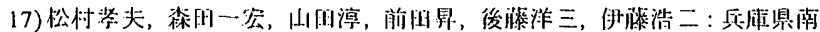

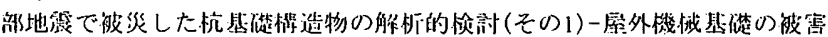

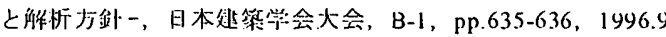

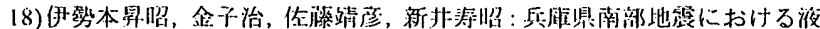

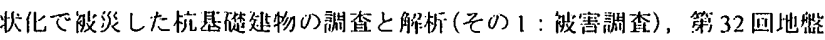
工学何烧発裴会, pp.919-920, 1997.7

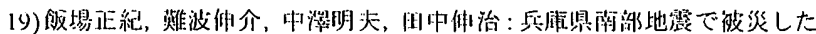

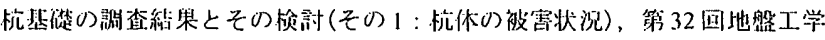
矿筧䧲表会, pp.1527-1528, 1997.7

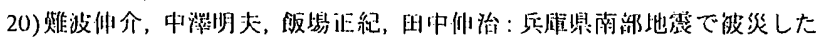

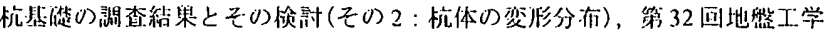

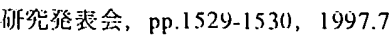

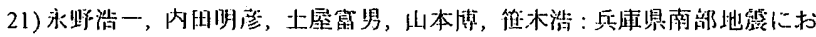

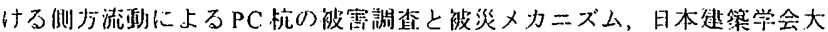
会, B-1, pp.437-438, 2002.8

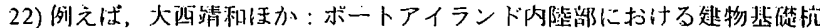

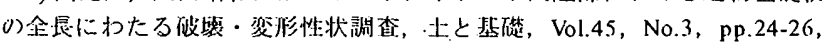
1997.3 など 


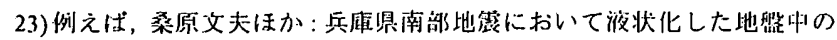

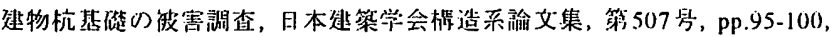
1998.5(ただし，一部に报っている既製コンクリート杭は対象となる)，俈仡

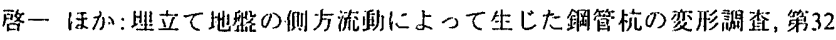

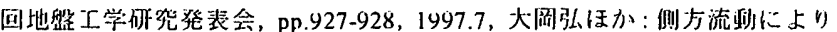

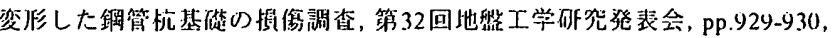

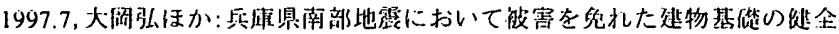

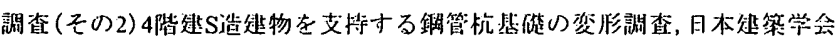
大会、B-1，pp.737-738，1997.9など

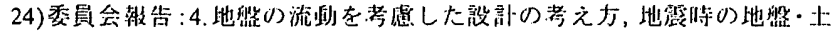

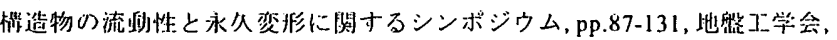
平成 10 年 5 月

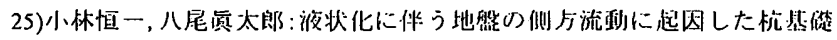
被害の颃討，日本建籍学会大会，B-1，pp.619-620，1996.9

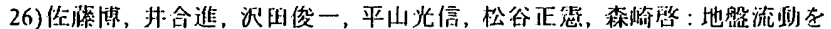

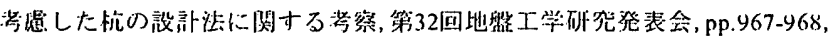
1997.7

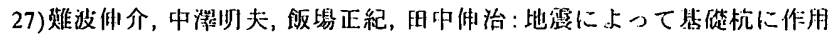
した被状化流動圧の試算，日本䖯築学会大会，B-1，pp.719-720，1997.9

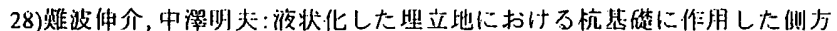

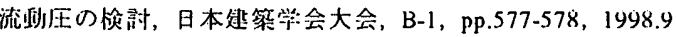

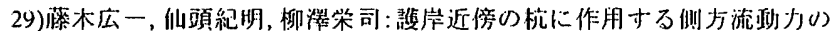

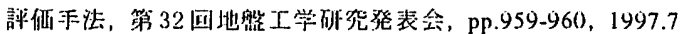

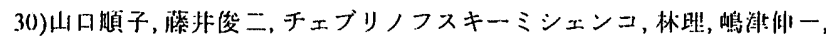

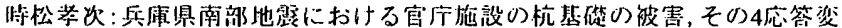
位法による杭の応力解析，日极建籍学会大会，B-1，pp.607-608，1996.9

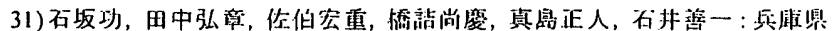

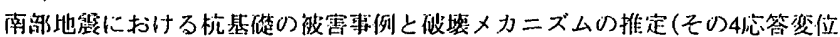
法に上万杭応力解析)，日本建築学会大会，B-1，pp.717-718，1997.9

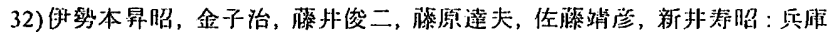

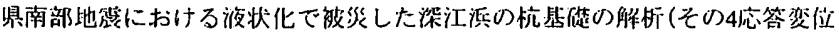
法に上万杭の応力解析 1)，日本建勧学会大会，B-1，pp.745-746，1997.9

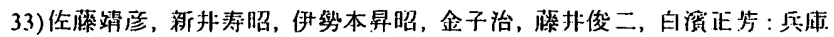

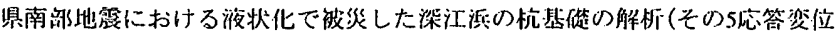
法に上万杭の㐫力解析 2)，日本越筑学会大会，B-1，pp.747-748，1997.9

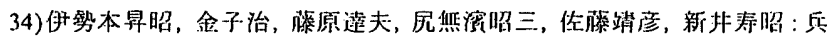

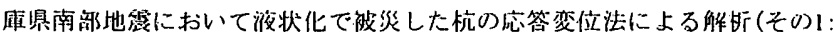
原仕㥞の杭の場合)，日本建筑学会大会，B-1，pp.525-526，1998.9

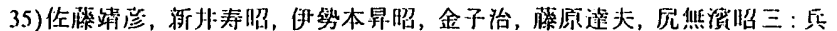

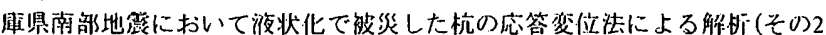

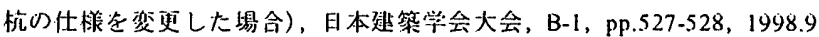

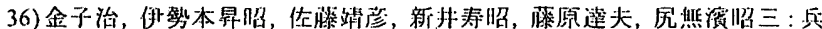

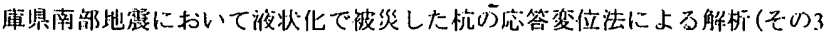

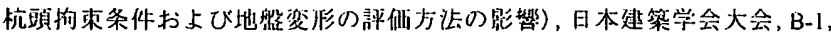
pp.529-530, 1998.9

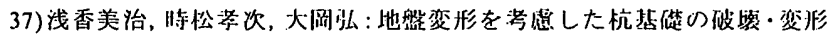
モ一ド解析, 日本建筑学会大会, B-1, pp.765-766, 1997.9

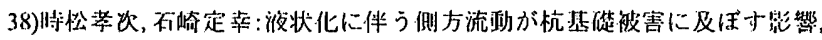
日本建策学会大会, B-1, pp.581-582, 1998.9

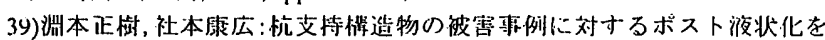

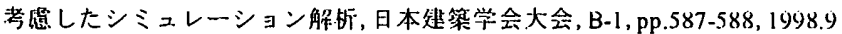

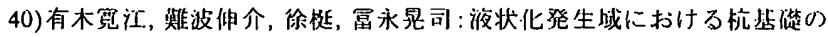

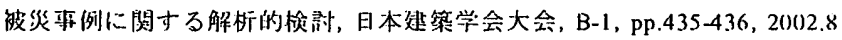

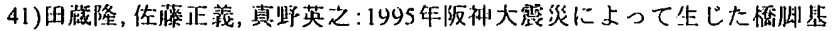

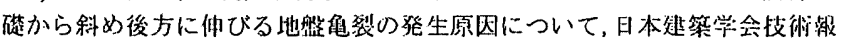
告集，第y号, pp.255-260, 1999.12

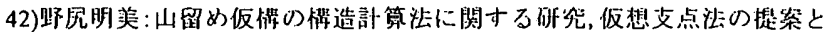

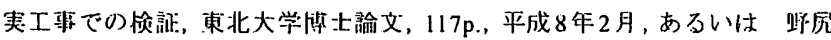

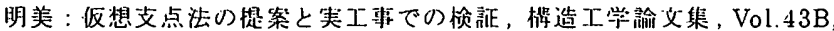
pp. $561-572,1997.3$

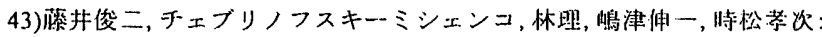

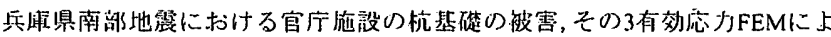

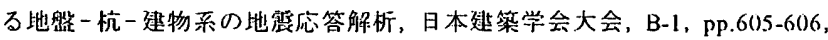
1996.9

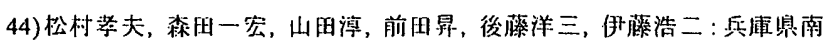

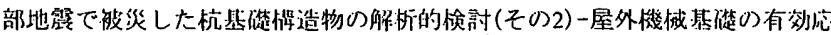

力解析一, 日本建籍学会大会, B-1，pp.637-638，1996.9

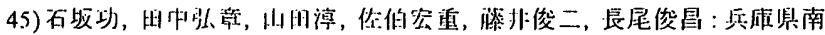

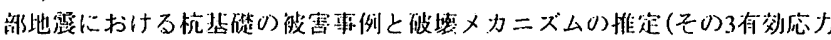

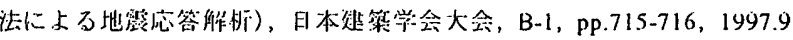

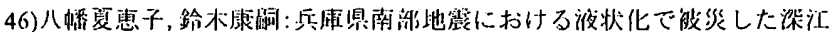

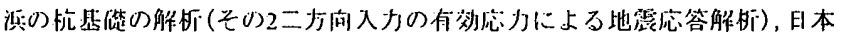
趜筑学会大会, B-1, pp.741-742, 1997.9

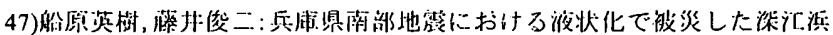

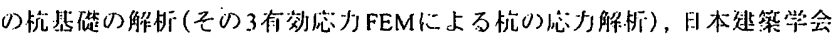
大会, B-1, pp.743-744, 1997.9

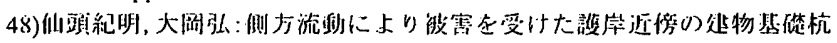

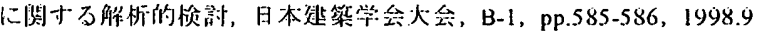

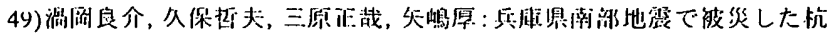

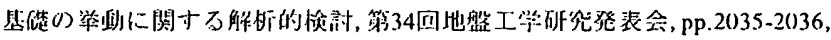
1999.7

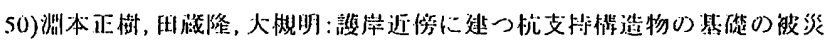
原因究明のための数优シミュレーション, 日本建筑管会大会, B-1, pp.519520, 1999.9

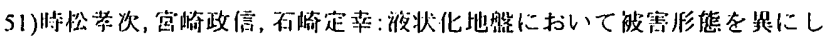

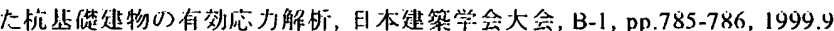

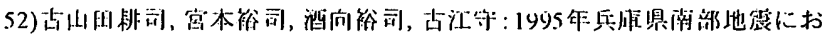

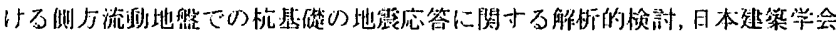

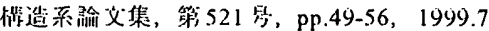

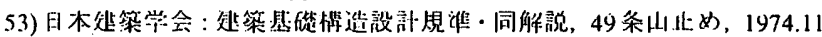

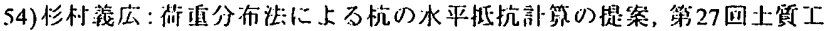
学(作觉狏表会, pp.1637-1640, 1992.6

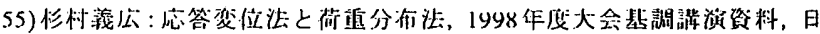

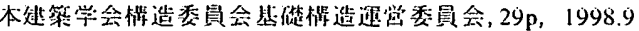

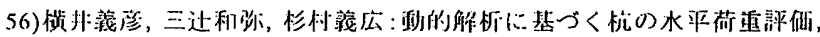

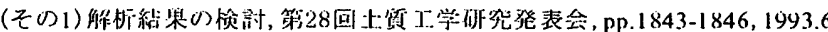

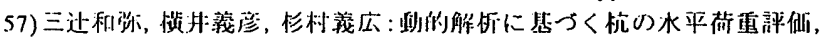

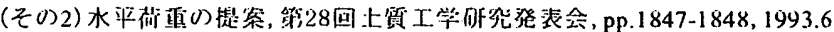

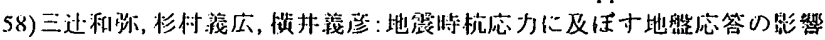
についての考察，El根处筑学会大会，B-1，pp.1687-1688，1993.9

59) Y. Sugimura, K. Fujiwara, T. Ohgi and Madan B. Karkee: Seismic Behavior of Piles Supporting Tall Buildings and the Consideration of Ground Response Effects in Design, Proc. of 4th Conf. on Tall Buildings in Seismic Regions, Los Angels Tall Buildings Structural Design Council and the Council on Tall Buildings and Urban Habitat, pp. 303-317, 1997.5

(10)Madan B. Karkee, Yoshihiro Sugimura and Kaoru Fujiwara: Significance of ground response effect in piles under earthquake loading, 2nd International Conf. on Earthquake Geotechnical Engineering, Lisbon. Vol.1, pp.44l-448, 1999.6

61)M. Hetenyi: Beams on Elastic Foundation, Ann Arbor: The University of Michigan Press, 255p., 1946

62)Y. Sugimura and M.B. Karkee: Nature of Damage to Pile Foundation of Buildings in Recent Earthquakes and Some Proposals for Seismic Design, Proc. of the 2nd U.S.-Japan Workshop on Soil-Structure Interaction. Tsukuba, BRI, Minisitry of Land, Infrastructure and Transport, Government of Japan, pp.441-455, 2001.3 63)Madan B. Karkee and Y. Sugimura: Analytical Investigation of Pile Foundation for Buildings Subjected to Large Lateral Ground Movement, 7th U.S. National Conference on Earthquake Engineering, Boston, Paper No. GS-2d, 2002.7

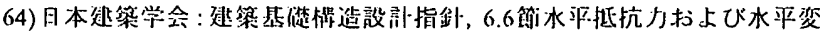
位, 2001.10

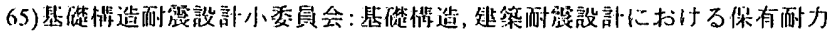
と婆杉性能, 日本棑管学会, pp.142, 1990.10

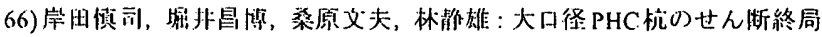

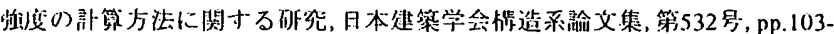
$110,2000.6$

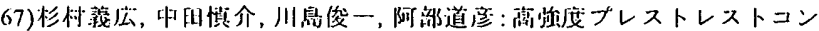

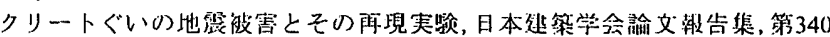
号, pp.40-50, 1984.6

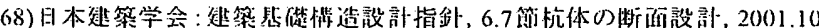

